ISSN (print): 1698-6180. ISSN (online): 1886-7995

www.ucm.es/info/estratig/journal.htm

Journal of Iberian Geology 38 (1) 2012: 175-190

http://dx.doi.org/10.5209/rev_JIGE.2012.v38.n1.39212

\title{
Active tectonics in the Malaga Basin: evidences from morphotectonic markers (Western Betic Cordillera, Spain)
}

\author{
Tectónica activa de la Cuenca de Málaga: evidencias en marcadores \\ morfotectónicos (Cordillera Bética Occidental, España)
}

\author{
J.M. Insua-Arévalo* 1, J.J. Martínez-Díaz ${ }^{1,2}$, J. García-Mayordomo ${ }^{3}$, F. Martín-González ${ }^{4}$ \\ ${ }^{1}$ Dpto. Geodinámica, Facultad de Ciencias Geológicas, Universidad Complutense. c/ José Antonio Nováis, 2. \\ 28004-Madrid. Spain \\ insuarev@geo.ucm.es,jmdiaz@geo.ucm.es \\ ${ }^{2}$ Instituto de Geociencias IGEO (CSIC-UCM), 28040 Madrid, Spain. \\ ${ }^{3}$ Área de Investigación en Peligrosidad y Riesgos Geológicos, Instituto Geológico y Minero de España, \\ c/La Calera, 1 Tres Cantos (Madrid) 28760, Spain. \\ Julian.Garcia@igme.es \\ ${ }^{4}$ Área de Geología-ESCET-, Universidad Rey Juan Carlos, C/Tulipán s/n, Mostoles 28933 Madrid, Spain. \\ fidel.martin@urjc.es \\ *corresponding author
}

Received: 06/12/2011 / Accepted: 19/03/2012

\begin{abstract}
The Malaga Basin is located in the westernmost part of the Betic Cordillera. This alpine cordillera in the south of Spain is the most active region of the Iberian Peninsula. Some of the most destructive earthquakes occurred historically in Spain took place within the Malaga Basin. In this work we focus on geomorphic and morphotectonic observations in the aim of finding active tectonic structures that could be seismogenic sources. First, we study the spatial arrangement and age of the Quaternary alluvial fan system as well as the drainage pattern of the basin, followed by the analysis of the distribution of regional markers like marine erosive surfaces and the extend of Pliocene marine deposits in the Malaga Basin. The tectonic structures inferred as active by the morphotectonic analysis are grouped into four main families: $\mathrm{N} 60^{\circ}-85^{\circ} \mathrm{E}$ folds associated with blind thrust faults, $\mathrm{N} 20^{\circ}-30^{\circ} \mathrm{E}$ and $\mathrm{N} 40^{\circ}-50^{\circ} \mathrm{E}$ high angle dip-slip faults, and $\mathrm{N} 165^{\circ}-170^{\circ} \mathrm{E}$ tear faults. Finally, their seismic potential in terms of maximum moment magnitude (Mw) is assessed by means of empirical relationships, varying between 6.0 and 7.0 depending on the hypothesis considered..
\end{abstract}

Keywords: active tectonics, Malaga basin, morphotectonics, seismic potential, Western Betic Cordillera.

Resumen

La cuenca de Málaga se sitúa en la parte más occidental de la cordillera Bética. En esta cordillera alpina del sur de España se han localizado algunos de los terremotos más destructivos ocurridos históricamente en la península Ibérica. En este trabajo se estudian algunos de los aspectos geomorfológicos de la cuenca del Málaga con el fin de identificar las estructuras tectónicas activas que pudiesen ser fuentes sismogénicas. Se estudia la distribución y edad del sistema de abanicos aluviales de la cuenca, así como la red de drenaje. También se analiza la distribución regional de marcadores tectónicos pliocenos, como superficies de erosión marina y 
los depósitos sedimentarios de este periodo transgresivo. Se han identificado varias estructuras tectónicas activas que han sido agrupadas en cuatro familias: pliegues $\mathrm{N} 60^{\circ}-85^{\circ} \mathrm{E}$ asociados con falla inversas ciegas, fallas de alto buzamiento con salto en la vertical $\mathrm{N} 20^{\circ}-30^{\circ} \mathrm{E}$ y $\mathrm{N} 40^{\circ}-50^{\circ} \mathrm{E}$, y fallas de transferencia $\mathrm{N} 165^{\circ}-170^{\circ} \mathrm{E}$. En base a relaciones empíricas se ha estimado un potencial sísmico para las fallas identificadas, obteniéndose valores de magnitud momento (Mw) entre 6,0 y 7,0.

Palabras clave: cordillera Bética occidental, cuenca de Málaga, morfotectónica, potencial sísmico, tectónica activa.

\section{Introduction}

The Malaga Basin is located in the western sector of the Betic Cordillera, which together with the African Rif, form the western end of the Mediterranean Alpine Orogen (Fig. 1A).

The Betic Cordillera is the most seismically and tectonically active area of the Iberian Peninsula. Some of the most important earthquakes that have occurred in the Iberian Peninsula have taken place in the Malaga Basin. The two most damaging events recorded in the area took place in 1494 (intensity VIII EMS-98) and 1680 (intensity VIII-IX EMS-98, causing 60 people killed, more than 100 casualties, and severe damage in several towns within the basin) (Martínez-Solares and Mezcua, 2002). However, the instrumental seismicity in the basin does not reflect the high degree of tectonic activity that can be observed as, for example, in the variable altitude distribution of Pliocene marine sediments.

Although the Malaga Basin is included in numerous tectonic studies (e.g.: Chamón and Quinquer, 1976; Estévez-González and Chamón, 1978a and b; Booth-Rea et al., 2003; Martín-Algarra et al., 2004), they are mainly focused on the complex relationships among the major structural complexes and tectonic sheets that make up the Internal Zone of the Betic Cordillera. Other studies try to analyze the deep cortical structure by geophysical surveys (e.g.: Torné et al., 1992, Torné and Banda, 1992; Barranco et al., 1990), and others deal with regional seismotectonic aspects centered on the occurrence of a medium-deep seismicity (which reaches $180 \mathrm{~km}$ depth in the area) and the geodynamic evolution of the Betic Cordillera (e.g.: Platt and Vissers, 1989; Zeck, 1996; Houseman, 1996; Lonergan and White, 1997; Morales et al., 1999; Calvert et al., 2000). The most detailed work dealing with the recent tectonic evolution of the Malaga Basin (since Tortonian) is from Sanz de Galdeano and López-Garrido (1991). They consider the basin controlled by E-W to $\mathrm{N} 70^{\circ} \mathrm{E}$ strike slip faults with a significant vertical component. They pointed out that these faults are cut by younger faults trending NW-SE, NE-SW and $\mathrm{N}-\mathrm{S}$ to NNE-SSW, which show a clear dominance of the vertical component in a general framework of regional uplifting of the Betic Cordillera (López-Garrido and Sanz de Galdeano, 1999). Most of these faults must be active if we consider them developed under the current tectonic regime ruling the region since the last $9 \mathrm{Ma}$ with $\sigma_{\text {Hmax }}$ trending NNW-SSE (Galindo-Zaldívar et al., 1993). Nevertheless, no clear apparent expression of active tectonic features have been documented within the basin, owing to the relative low rate of deformation and the presence of soft sediments filling up the basin (marls and sandstones, mainly) easily erodible. These reasons make morphotectonic studies a powerful tool for identifying active features. In this sense, Capote et al. (2002) and Insua-Arévalo et al. (2004a) pointed out some geomorphic aspects related to the active folding of the Cartama Sierra, in the central part of the basin.

In this paper some morphotectonic features of the Malaga Basin are studied aimed at identifying active tectonic structures, concerning to several active faults and folds, for which its seismogenic potential is estimated eventually by using empirical relationships.

\section{Geological setting}

The Malaga Basin is one of the intermontane basins of the Betic Cordillera that have been formed since the Tortonian (Sanz de Galdeano and Vera, 1992). It is an elongated E-W basin drained by the Guadalhorce River until it flows into the Mediterranean, south of Malaga City (Fig. 1B). The basin is bounded by the Malaga Mountains to the north, the Mijas Sierra to the south, and by the Alboran Sea (Mediterranean Sea) to the east. The western boundary is diffuse, controlled mainly by the Blanca and Las Nieves Sierras. A remarkable feature is the Cartama Sierra, rising from the center of the basin with an elongated morphology trending N70-80E.

The surrounding mountains of the basin, as well as Cartama Sierra, consist of basement materials (schists, gneisses, peridotites, sandstones, marbles) from the Malaguide and Alpujarride Complexes which belong to the Internal Zones of the Betic Cordillera (Chamón and Quinquer, 1976; Estévez-González and Chamón, 1978a, b). During the Burdigalian period took place the gravitational emplacement of the sands and clays of the Neonumidian Formation (Bourgois, 1978). The main infill of the basin started from Late Tortonian. Since this time the deposits can be considered belonging to the basin as we know it today (López-Garrido and Sanz de Galdeano, 1999). 

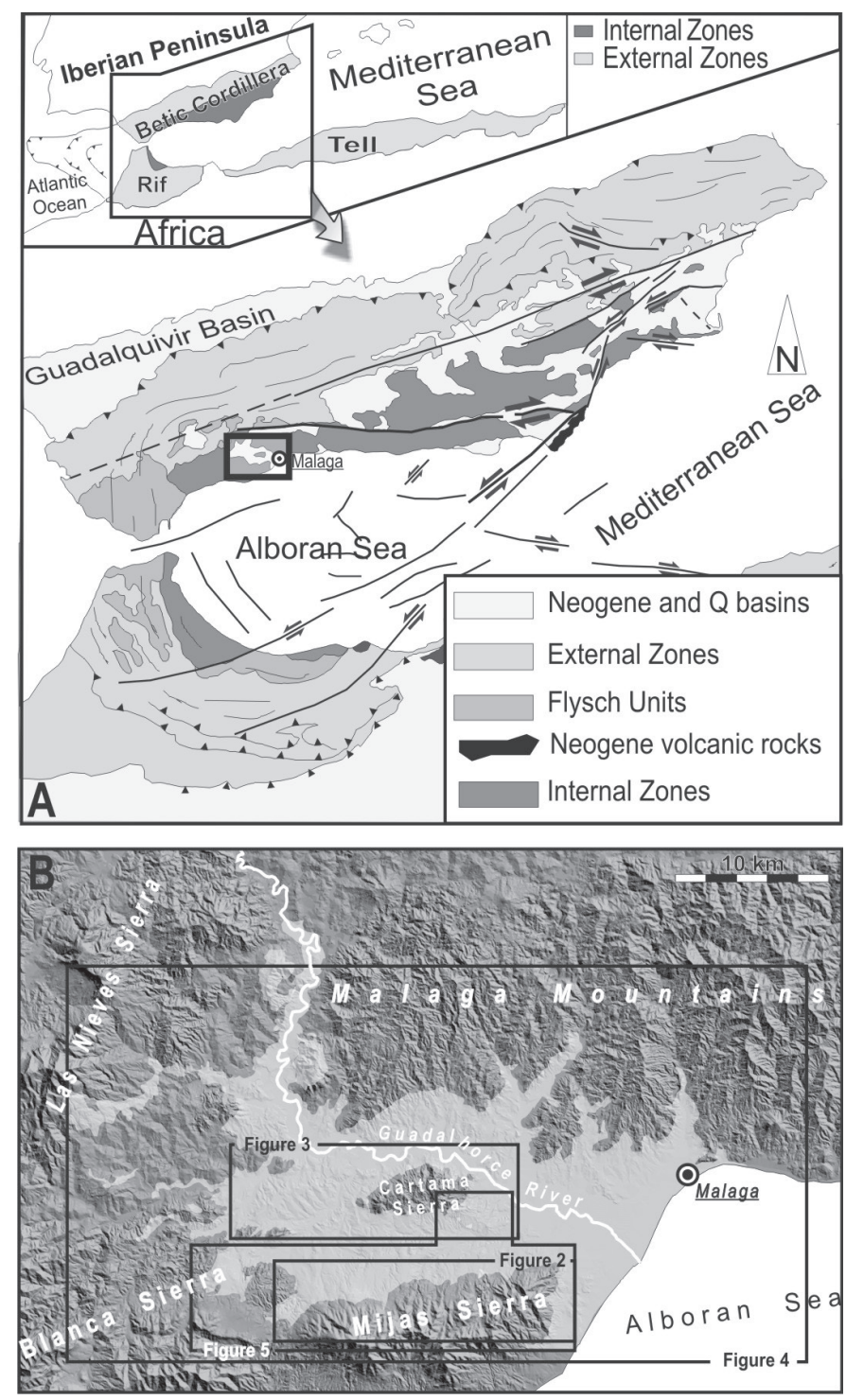

Fig. 1.- A. Regional frame of the Malaga Basin within the Betic Cordillera. B. Shaded digital terrain model of the Malaga Basin (lighter gray) where the different areas of study are located and labeled with their corresponding figure number.

Fig. 1.- A. Marco regional de la Cuenca de Málaga dentro de la Cordillera Bética. B. Modelo digital del terreno sombreado de la Cuenca de Málaga (en gris claro) en el que se localizan las diferentes zonas de estudio etiquetadas con el número de figura con el que aparecen en este trabajo.

During the Late Tortonian, transgressive coarse material formed by bioclastic calcarenites, conglomerates and sandstones was deposited throughout the basin, reaching thickness exceeding $300 \mathrm{~m}$ (Sanz de Galdeano and López-Garrido, 1991). After the Messinian, when the basin remained emerged, a new marine transgression occurred during the Pliocene (Guerra-Merchán et al., 2000). At this period the basin was filled up with sand and bluegray marls and conglomerates at the edges, in a fan-delta sedimentary environment. The thickness of these deposits exceeds $400 \mathrm{~m}$ in the eastern basin, decreasing to the north and west (López Garrido and Sanz de Galdeano, 1999). Within these deposits discontinuities associated with tectonic events have been described (Guerra-Merchán et al., 2000). After this transgression, the sediments found in the basin are continental, with the exception of the coastal area. They are basically piedmont deposits, travertine and alluvial and colluvial sediments.

The basin has been tectonically controlled mainly by $\mathrm{E}-\mathrm{W}$ to $\mathrm{N} 70^{\circ} \mathrm{E}$ strike-slip faults with important vertical component (Sanz de Galdeano and López Garrido, 1991). E-W folding has been described associated with the internal structure of the sierras surrounding the basin: Mijas Sierra (Andreo and Sanz de Galdeano, 1994) and Malaga Mountains (González-Lodeiro et al., 1996). Even the Cartama Sierra, within the basin, is formed by an anticline (Mon, 1971).

\section{Morphotectonic analysis}

In order to identify the main active tectonic structures in the Malaga Basin, we have selected three different issues to look at: (1) the alluvial fan of the southern border (Mijas Sierra), (2) the folded structures of the central part (Cartama Sierra), and (3) the variation of vertical movements throughout the basin after the Pliocene.

\subsection{The alluvial fans of the Mijas Sierra}

The Mijas Sierra, made up mainly of Triassic marble, has an elongated morphology trending E-W, reaching height up to 1,150 m asl. Many alluvial fans have formed around it, being those of its northern slope the best preserved. These systems of alluvial fans are deposited over the marine Pliocene deposits of the Malaga Basin (Fig. 2 ). They are made up of pebbles and boulders of marble with a distribution of grain sizes and degree of roundness that fits a pattern of proximal-distal facies typical of this type of sedimentary systems. These fans show a calcareous cementation with a variable development. This kind of alluvial system can be associated with a dry environment where the fans developed in arid climate conditions (Schumm, 1977). Currently the alluvial fans, as well as the underlying marine Pliocene sediments, show a significant degree of erosion due to the incision of the drainage network, which can be associated with the current regional uplift (Schoorl and Veldkamp, 2003).

\section{Depositional phases}

We have distinguished three depositional phases within the alluvial system regarding on the type of deposit (debris flow or sheet flow), the alluvial architecture, the slope of the fan and the degree of cementation. By using 
the same methodology Silva (1994) described also three phases for the arid alluvial fans located in SE Spain. The three depositional phases of the alluvial system in the Mijas Sierra are: (1) The first depositional phase (1DP) includes debris-flow deposits with heterometric grain sizes (decimeter, up to 1 meter) slightly rounded deposited in an onlap gradational proximal style, generating convex slopes surfaces up to $8^{\circ}$. These fans are completely cemented by reddish carbonates reaching more than $30 \mathrm{~m}$ thick. (2) The second depositional phase (2DP) is formed mainly by debris-flow deposits (some sheet-flow can also be identified) of heterometric grain size (centimeter to decimeter). They were deposited in progradational fans with off-lap distal aggradation, generating concave surfaces with slopes ranging from $3^{\circ}$ in the proximal areas to be subhorizontal in distal parts. These materials show red calcareous cement (up to $10 \mathrm{~m}$ thick). (3) The third depositional phase (3DP) is characterized by a sheet-flow predominant deposit, with centimeter grain size in a reddish clayed matrix not cemented. Both, the sedimentary architecture and the slope of this phase vary along the moun- tain front. At the westernmost part, it can be observed an off-lap distal aggradation, with almost horizontal surfaces; meanwhile at the eastern part the style is off-lap proximal aggradation, with concave slopes ranging from subhorizontal in distal areas up to $12^{\circ}$ at proximal.

\section{Tectonic features affecting the alluvial fan system}

According to the spatial distribution of the three depositional phases along the mountain front, it can be observed that there are two different sectors (Fig. 2): (1) the western sector has a progradational sequence that includes all the three phases identified in a distal aggradational distribution: the 2DP prograding with respect to the $1 \mathrm{DP}$, and the 3DP to the 2DP. This distribution points out a tectonic uplift of the source area (Silva et al., 1992), meaning that the Mijas Sierra is growing up in this sector coherently with the location of the highest peaks of the sierra. (2) The eastern sector, we have hardly identified some small outcrops of 1DP (barely mappable at the scale of work). The 2DP in this sector have also the maximum extension, similarly to the western sector. It is noteworthy that 3DP depo-

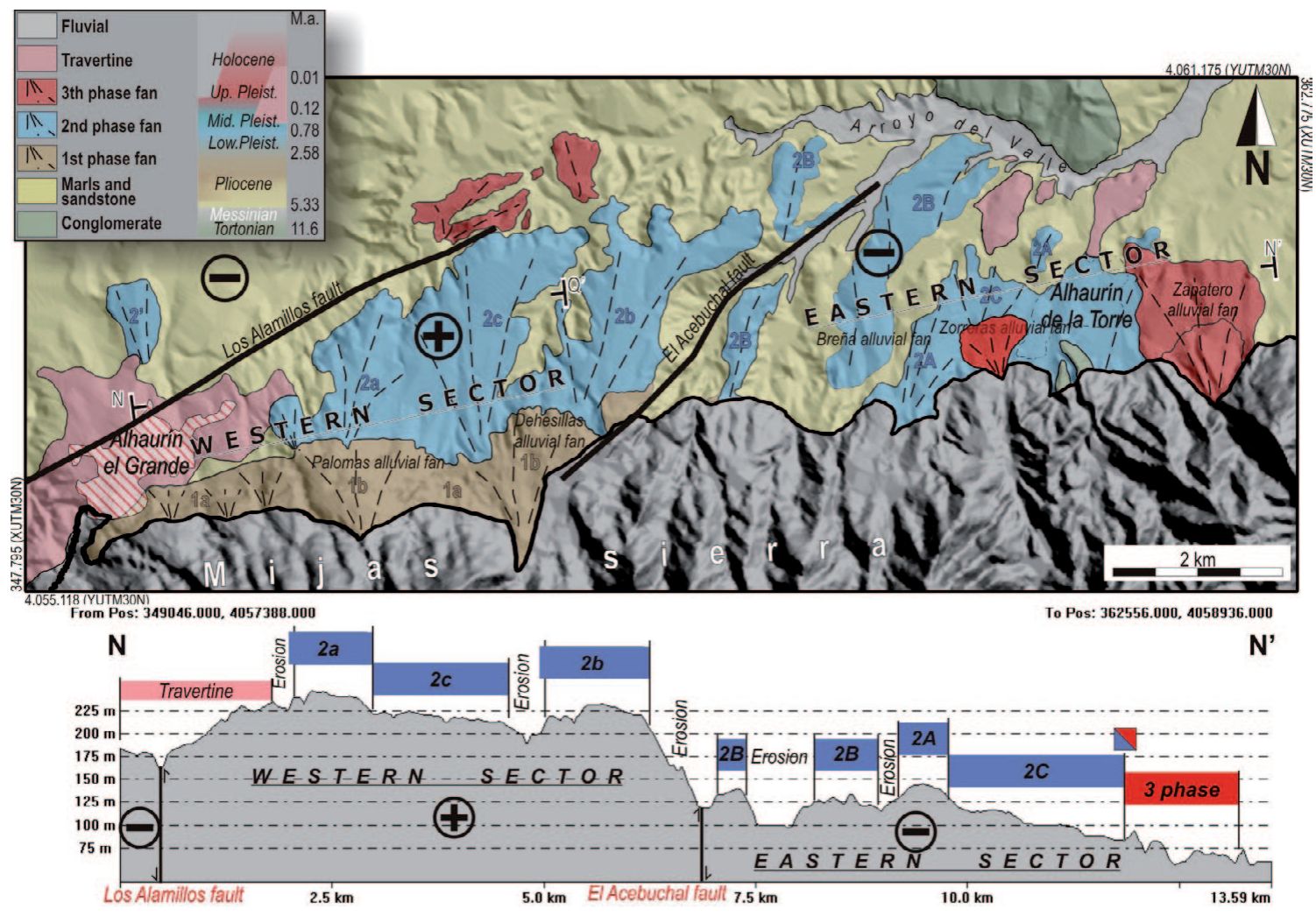

Fig. 2.- Alluvial fan system of the Mijas Sierra. Three different depositional phases are identified. The possible range of age of each depositional phase is displayed inside the legend. a longitudinal topographic profile along the alluvial system is presented at the bottom. Two different sectors controlled by dip-slip fauts can be identified. The symbol (+) denotes uplift respect to the symbol of (-).

Fig. 2.- Sistema de abanicos aluviales de la Sierra de Mijas. Se han distinguido tres fases deposicionales cuyo posible rango de edad se puede observar en la leyenda. En la parte baja de la figura se muestra un perfil topográfico longitudinal a lo largo del sistema aluvial en el que se pueden distinguir dos sectores controlados por fallas con salto en la vertical. El signo (+) indica levantamiento respecto a los sectores marcados con el signo (-). 
sits are not progradational with respect to the 2DP, but they are deposited on top of it in their proximal zone. This is in contrast with the location of the 3DP deposits in the western sector. The distribution of the depositional phases in the eastern sector is in relation with an ancient source area, with no tectonic activity in this part of the Mijas Sierra.

The variation on the distribution of depositional phases remarks the different tectonic activity along the mountain front. This is also observed within the own alluvial system too. As shown in the topographic profile of Figure 2 , the western sector has a higher topographic elevation than the eastern sector. This fact agrees with the differential uplift of the sierra. The offset between the two sectors is controlled by the El Acebuchal fault, a NE-SW trending fault inferred by its geomophological expression that could be affecting the deposits of the 2DP belonging to the eastern sector. No fault plane has been identified at field, maybe because of the easily erodible material together with the low slip rate of the fault. We have measured an offset of $44 \mathrm{~m}$ attending to the height of the depositional surface affected by the fault. There is no absolute age dating available for each depositional phase. We can assume an age ranging from Lower to Middle Pleistocene $(1.8-0.12 \mathrm{Ma})$ for the 2DP by comparison with the ages obtained by Silva et al. (1992) attending to the development of calcrete in the fans of SE Spain. This would give us a vertical slip rate for the El Acebuchal faul varying between 0.02 to $0.35 \mathrm{~m} / \mathrm{ky}$. We consider a value between 0.05 to $0.1 \mathrm{~m} / \mathrm{ky}$ as representative for this fault attending to its depositional relationship within the 2DP. These values are also consistent for the tectonic environment where the fault is located within the Betic Cordillera (e.g.: Silva et al. 2003; Martínez-Díaz, 2000).

At the western end of the alluvial system, the Los Alamillos fault runs almost parallel to the El Acebuchal fault. No fault plane has been identified at field in this case either. This fault has been inferred also by its geomophological expression. It seems to be affecting to the 2DP deposits of the western sector. An offset of $40 \mathrm{~m}$ has been measured in this unit. We consider a value between 0.05 to $0.1 \mathrm{~m} / \mathrm{ky}$ as representative for the vertical slip rate of this fault, assuming the same premises as above.

\subsection{The folded central part of the basin}

The presence of the Cartama Sierra in the center of the basin is a remarkable characteristic of the Malaga Basin (Fig. 1 and 3). The sierra is made up of Triassic marble, being the top of a metamorphic unit (shales, quartzites, anfibolites and gneises) belonging to the Alpujarride Complex. It has an elongated morphology trending $\mathrm{N} 60^{\circ}$ $70^{\circ} \mathrm{E}$ reaching a height up to $400 \mathrm{~m}$ asl. All the Tertiary sedimentary deposits in the basin (Burdigalian, Tortonian and Pliocene) are represented around the Cartama Sierra.

To the west of the Cartama Sierra, nearby the town of Villafranco de Guadalhorce, there is an area of relatively higher topography (Fig. 3). This area shows morphology very similar to the Cartama Sierra. The main difference is that in this case the area is mostly made up of Pliocene marine sediments, reaching a height of $120 \mathrm{~m}$ asl.

\section{Post-Pliocene activity of the folded structures}

The structure of the Cartama Sierra is defined by an asymmetric anticline verging towards the north and affecting the basement materials (Fig. 3). The marine Pliocene sediments are also affected. At the northern flank the deposits are dipping around $30^{\circ}$ towards the north (at western and eastern of the town of Cartama). At the southern part, the Pliocene deposits dip around $18^{\circ}$ toward the south (to the west of the town of Torrealqueria). This variation of dip between the two limbs of the fold is consistent with an asymetrical anticline, evidencing its activity after the Pliocene marine sedimentation. Considering both pericline terminations of this fold, it can be observed also an asymmetry longitudinal to the fold axe. On the one hand, the western termination is well defined with a clear plunge of the fold axe getting under the Pliocene deposits. On the other hand the eastern one is quite diffuse due to the existence of an ancient low angle normal fault trending NNW-SSE represented by a wide band $(\sim 1 \mathrm{~km})$ of stretched Alpujarride and Malaguide units.

Analogously, the area of Villafranco de Guadalhorce shows an anticline structure, but in this case the folding affects directly the Pliocene marine deposits, which reach a thickness greater than $500 \mathrm{~m}$. In this case, the asymmetry it is only transversal, with a long limb dipping gently (aprox. $5^{\circ}$ ) toward the south.

\section{Morphotectonic analysis of the folded structures}

We have analyzed the drainage network and river patterns of the central part of the Malaga Basin. This aspect is one of the most commonly used in order to identify signs of Quaternary tectonic activity (e.g.: Schumm et $a l ., 2000)$. The drainage pattern in both studied anticlines present common characteristics. It is characterized by a conspicuous asymmetry, with shorted and more embedded creeks on the northern slope than on the southern. The watershed divide is displaced towards the North regard to the central part of the sierra, following the axial trace of the anticline. On both slopes, the creeks run perpendicular to the watershed divide, as well as to the fold axial trace, which is an indication of the controlling of the drainage exerted by the growth of the fold (Jackson et al., 1996). 


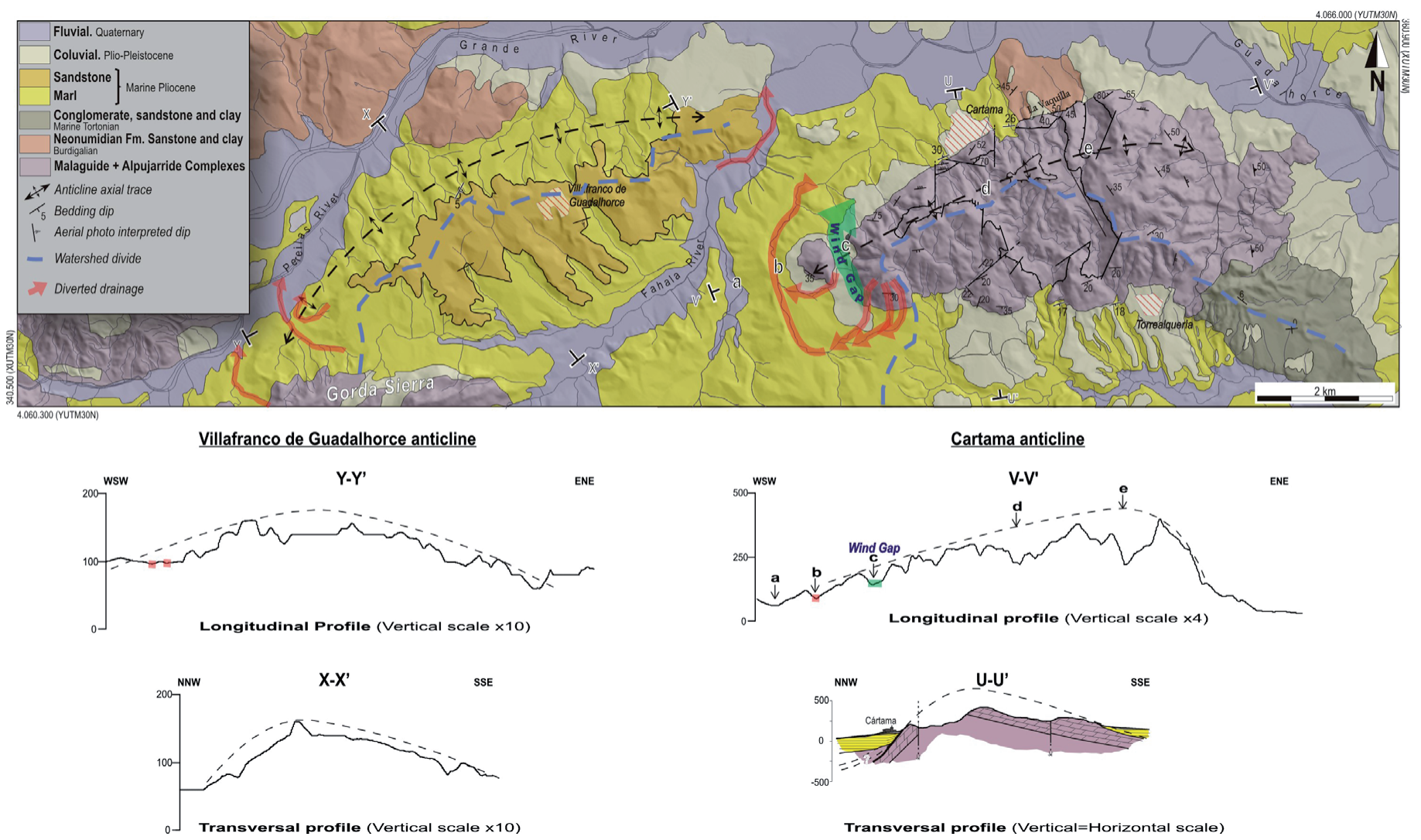

Fig. 3.- Folded central part of the Malaga Basin. The geological map shows the affected Pliocene marine sediments. The drainage network is also displayed. It can be observed the diverted channel located in the area where the anticlines are propagating laterally. The profiles show the different topography in relation to the growth of the asymmetric anticlines verging towards the NNW.

Fig. 3.- Plegamiento de la zona central de la Cuenca de Málaga. En el mapa geológico se puede observar los materiales pliocenos marinos afectados. Se ha representado también la red de drenaje en la que se puede observar varios canales afectados por la propagación lateral de los anticlinales. En los perfiles se puede observar la variación de la altura topográfica relacionada con el crecimiento de los anticlinales asimétricos con vergencia hacia el NNO.

Some of the creeks located at the pericline termination of the anticlines are diverted by the lateral propagation related to the growth of the fold. This aspect is clearer at the western termination of the Cartama anticline, where several creeks are surrounding the sierra from the south slope to the north. The longitudinal profile of the Cartama anticline in Figure 3 shows how the topographic height of the creeks rise up from WSW at the points marked as $a$ and $b$, leaving even a wind gap (abandoned channel) at point $c$. The envelope of the topographic profile show how the highest point $(e)$ is clearly displaced from the middle point $(d)$. This fact points to a preferential lateral propagation of the Cartama fold to the west, probably due to the presence of the major tectonic structure located at its eastern termination. On the contrary, the lateral propagation of the Villafranco de Guadalhorce anticline seems to be towards both sides, attending to the symmetry of the longitudinal profile and the occurrence of diverted creeks at both lateral terminations, which can be interpreted as a symmetrical growing of the fold.
The external morphology of these folds leads us to consider them related to blind faults, in the same way that other folding referenced worldwide (c.f. Delcaillau et al., 2007)

\subsection{Post-Pliocene vertical movements throughout the basin}

The existence of a transgressive period in currently emerged basins provides an excellent opportunity for estimating vertical movements of the region because, once the sea level for a certain time is known, it can be used as a marker for calculating the subsequent vertical movement of the basin. In the Malaga Basin, it has been described a general uplifting from the Tortonian (Sanz de Galdeano and López-Garrido, 1991) which is part of the regional formation of relief in the Betic Cordillera (e.g.: Braga et al. 2003; Sanz de Galdeano and Alfaro, 2004). We have analyzed the spatial distribution of the topographic height of both, the erosional and sedimentary marine markers produced during the Pliocene transgression throughout 
the basin. The marine transgression took place during the Early Pliocene (Guerra-Merchán et al., 2000). We have compared the current height of the Pliocene deposits and marine terraces to the sea level at the third-order cycle TB 3.4 following the eustatic curve of Haq et al. (1987). The maximum sea level for this period was $+90 \mathrm{~m}$ (above the current sea level). Subsequently, sea-regression took place in the basin, resulting in widespread erosion and the onset of a continental sedimentary environment.

The vertical movement is not uniformly distributed, which means that the area is having a complex deformation controlled not only by faults or isostatic uplift, but by important processes of folding, as discuses below.

\section{Analysis of the height distribution of the Pliocene sedi- ments}

Pliocene deposits are widely spread within the basin, being the most extended formation. At a regional level, they show a general horizontal disposition. Nevertheless, locally they can dip up to $30^{\circ}$ in association with different tectonic structures, such as the folding of the Cartama Sierra (see Section 3.2.) or in relation with the folding of the Mijas Sierra, as it will be described in the subsection below. We have analyzed the topographic height of the Pliocene marine deposits outcropping throughout the basin (Fig. 4).

Even though the degree of erosion of the marine deposits during the subsequence regression is indeterminate, we can assume that it has been homogeneous throughout the basin. That implies that the vertical movement estimated at each site will provide a minimum value, since the top could have been removed. Additionally, since they were deposited all under the same regional level, the relative variations of height can be attributed to a tectonic origin.

Pliocene deposits reach $500 \mathrm{~m}$ asl at the west part of the basin, while near the current coast line they are lie below the reference level $(+90 \mathrm{~m})$, marking a clear tendency to increase in elevation from $\mathrm{E}$ towards $\mathrm{W}$. This tendency is partially accommodated at the westernmost part of the basin by two faults: La Robla fault and Sierra de las Nieves fault. These faults have been identified by theirs geomorphological expression. Attending to the height of the Pliocene deposits on both sides of each fault, we have estimated a vertical offset of 100 and $150 \mathrm{~m}$, respectively. Considering the age of the deposits, we have calculated a vertical slip rate between 0.02 and $0.03 \mathrm{~m} / \mathrm{ky}$, which is quite similar to those obtained for the faults located at the southern border of the basin (See Section 3.1.).

Another secondary tendency can be observed from $\mathrm{N}$ to $\mathrm{S}$, but in this case no fault seems to be involved. Nevertheless, the Pliocene sediments above the reference level are located mainly on both edges of the basin, remaining the central part under subsidence. This variation would be related to the uplift of the mountains that limit the ba$\sin$. However, the variation is noticeably higher towards the South edge. This asymmetry could be related to a greater uplift of the Mijas Sierra in comparison with the Malaga Mountains, which is consistent with the relief of the two sierras, being the Mijas Sierra much higher. The gradual relative variation of heights in a N-S trend could fit to a process of deformation by folding (e.g.: Chamón and Quinquer, 1976; Estévez-González and Chamón, 1978a; Andreo and Sanz de Galdeano, 1994; Capote et al., 2002).

Some anomalous values of height, which do not fit to the trends outlined above, have been related to two faults with a clear topographic expression: Campanillas fault and Guadalmedina fault. As we did with the other two faults, attending to the height of the Pliocene deposits on both sides of the fault, we have estimated a vertical offset of 90 and $160 \mathrm{~m}$, respectively. We have calculated a vertical slip rate between 0.02 and $0.03 \mathrm{~m} / \mathrm{ky}$, which is in the same range than those obtained for the La Robla fault and Sierra de las Nieves fault, and consistent with the regional tectonic setting.

\section{Analysis of the Pliocene marine erosive surfaces}

Several marine erosive surfaces developed over the marble of Mijas Sierra and its western continuation to the Blanca Sierra, as well as in the Tortonian conglomerates at El Romeral site (SE Cartama Sierra) have been identified (Fig. 5).

In broad terms, the slopes of the highest reliefs made up of Alpujarride rocks show the steepest slopes, being the flat areas those made up of Plio-Quaternary sediments. However, several exceptions to this general pattern can be observed in relation to marine erosive surfaces developed during the Pliocene transgression. The topographic height and slope of the marine erosive surfaces are controlled by eustatic variations, as well as by a heterogeneous tectonic activity throughout the basin.

On the SE of Cartama Sierra is located the El Romeral site. At this site up to three subhorizontal marine erosive surfaces developed on the Tortonian conglomerates and sandstones can be observed. Furthermore, two cliffs are also observed, allowing the identification of three paleocoastlines $(+62 \mathrm{~m},+87 \mathrm{~m}$ and $+102 \mathrm{~m}$ above current sea level). We consider these levels as three different sealevel high stands (SLHS), since vertical tectonic movement at the site is not significant attending to the topographic height of the Pliocene marine deposits (see Fig. 4 and the subsection above). Subhorizontal Pliocene marine sediments onlap the uppermost cliff developed during the $+62 \mathrm{~m}$ acsl SLHS (Fig. 6A). This fact permits us to consider this level as the oldest SLHS during the Plioce- 


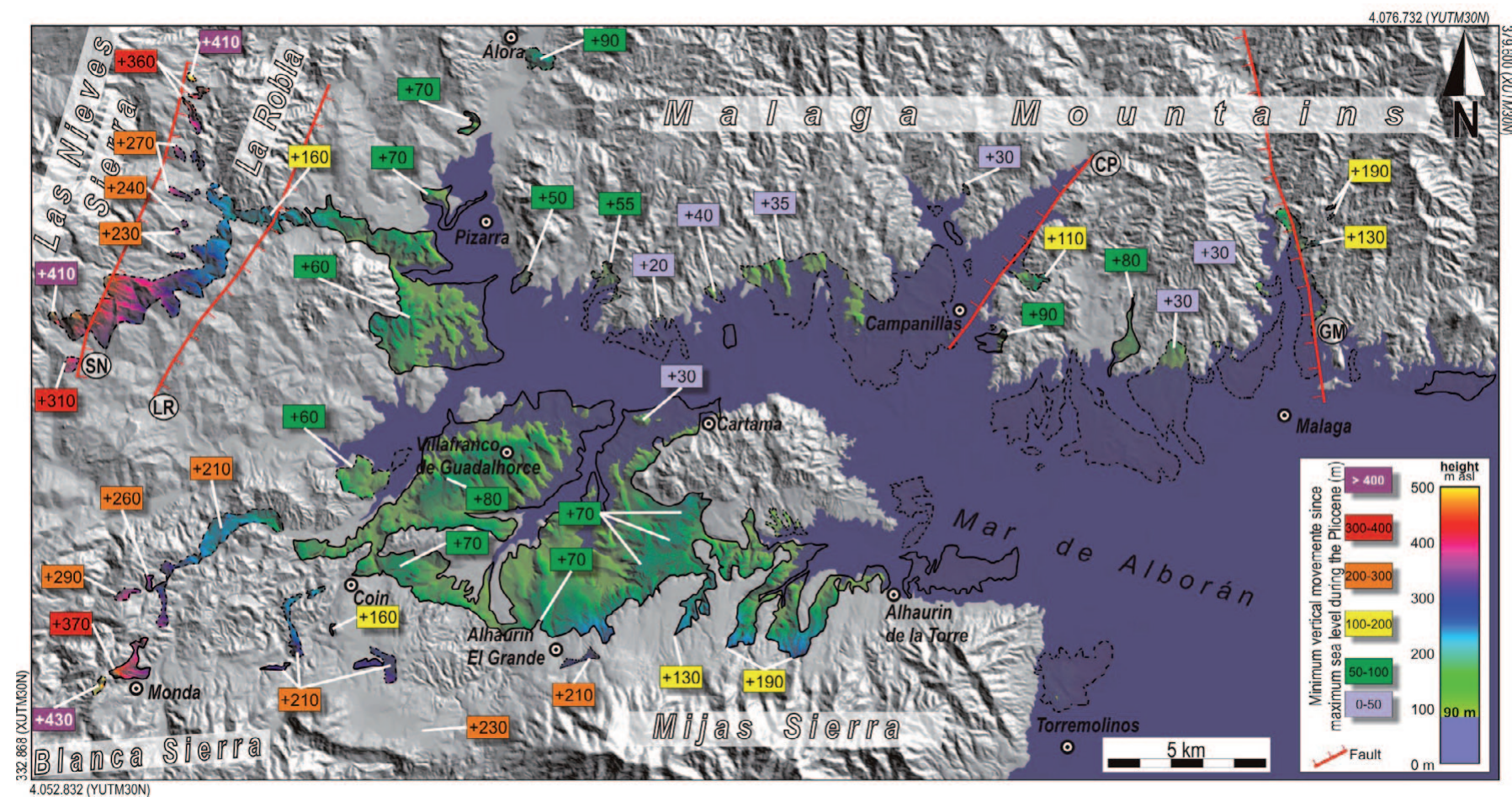

Fig. 4.- Topographic distribution of the Pliocene marine deposits throughout the basin. A rise in sea level of $+90 \mathrm{~m}$ has been simulated (in dark blue), corresponding to the maximum level reached by the sea during the Early Pliocene (Haq et al., 1987). The estimated minimum vertical movement has been labeled at each representative site. Faults identified attending to the relative variations of the elevation of the deposits are also displayed. (SN) Sierra de las Nieves Fault, (LR) La Robla Fault, (CP) Campanillas Fault, (GM) Guadalmedina Fault.

Fig. 4.- Distribución de las alturas topográficas de los sedimentos marinos pliocenos en la cuenca. Se ha simulado una elevación del nivel del mar de $+90 \mathrm{~m}$ (en azul oscuro) que corresponde con el máximo nivel que alcanzó el mar durante el Plioceno Inferior (Haq et al., 1987). Las etiquetas de colores muestran el movimiento vertical mínimo para cada afloramiento. Las fallas representadas han sido identificadas atendiendo a las variaciones locales de altura de los depósitos. (SN) Falla de la Sierra de las Nieves, (LR) Falla de La Robla, (CP) Falla de Campanillas, (GM) Falla del Guadalmedina.

ne, being the highest (+102 $\mathrm{m}$ asl) ande best developed the youngest one. As we pointed out above, following the eustatic curve of Haq et al. (1987), the maximum sea level for this period was $+90 \mathrm{~m}$ asl. This allows us to calculate a slightly uplift of $12 \mathrm{~m}$ for the area, which fit the values obtained in the previous subsection.

At Los Nebrales site (Fig. 5), in the western continuation of the Mijas Sierra, a subhorizontal $\left(1^{\circ}\right)$ erosive surface entirely developed over the Alpujarride marbles can be observed. Some Pliocene marine deposits have been found laying on this surface (Fig. 6B) so dating it as Pliocene. This surface was developed with a maximum SLHS located at $+355 \mathrm{~m}$ acsl, giving an uplift of $265 \mathrm{~m}$ since the Pliocene, which is consistent with the values obtained above for this area. Nearby, two more paleocoastlines have been identified ( +335 and $+345 \mathrm{~m}$ acsl) that fit the pattern of number and ages of SLHS described at El Romeral site. The discrepancy between the absolute values of sea level variation between the minimum and the maximum SLHS (40 m at Los Nebrales, and $20 \mathrm{~m}$ at El Romeral) should be associated to the tectonic uplift of Los Nebrales site, which is partially masked due to the sea level rise during the recorded period.
We have also distinguished three marine erosive surfaces at Llanos de Peñaprieta site. They show a progressive tilting, being the lowest and more tilted the oldest one. Pliocene marine sediments lay over the oldest surface dipping consistently $\left(25^{\circ}\right)$ (Fig. 6C). The uplift at this site, attending to the height of the paleocoastlines is of 225 $\mathrm{m}$ since Early Pliocene, which is barely higher, but consistent with the values obtained considering the position of the Pliocene marine deposits for this area. The tilted surfaces reflect a tectonic deformation that could be explained with the folding of the Mijas Sierra (Andreo and Sanz de Galdeano, 1994).

At Alhaurin el Grande site, we could identify just one tilted erosive marine surface. This surface even affects part of the oldest alluvial fan deposits, where a cliff was developed (Fig. 6D). These facts would date part of the alluvial fans as Early Pliocene within a progradational sedimentary sequence. We cannot assign any of the SLHS described above to this surface because of the lack of other surfaces. In terms of uplift, attending to the height of the paleocoastline, the area is uplifted by $410 \mathrm{~m}$, which is an anomalous datum if we consider the E-W trending pointed out with the analysis of distribution of topogra- 


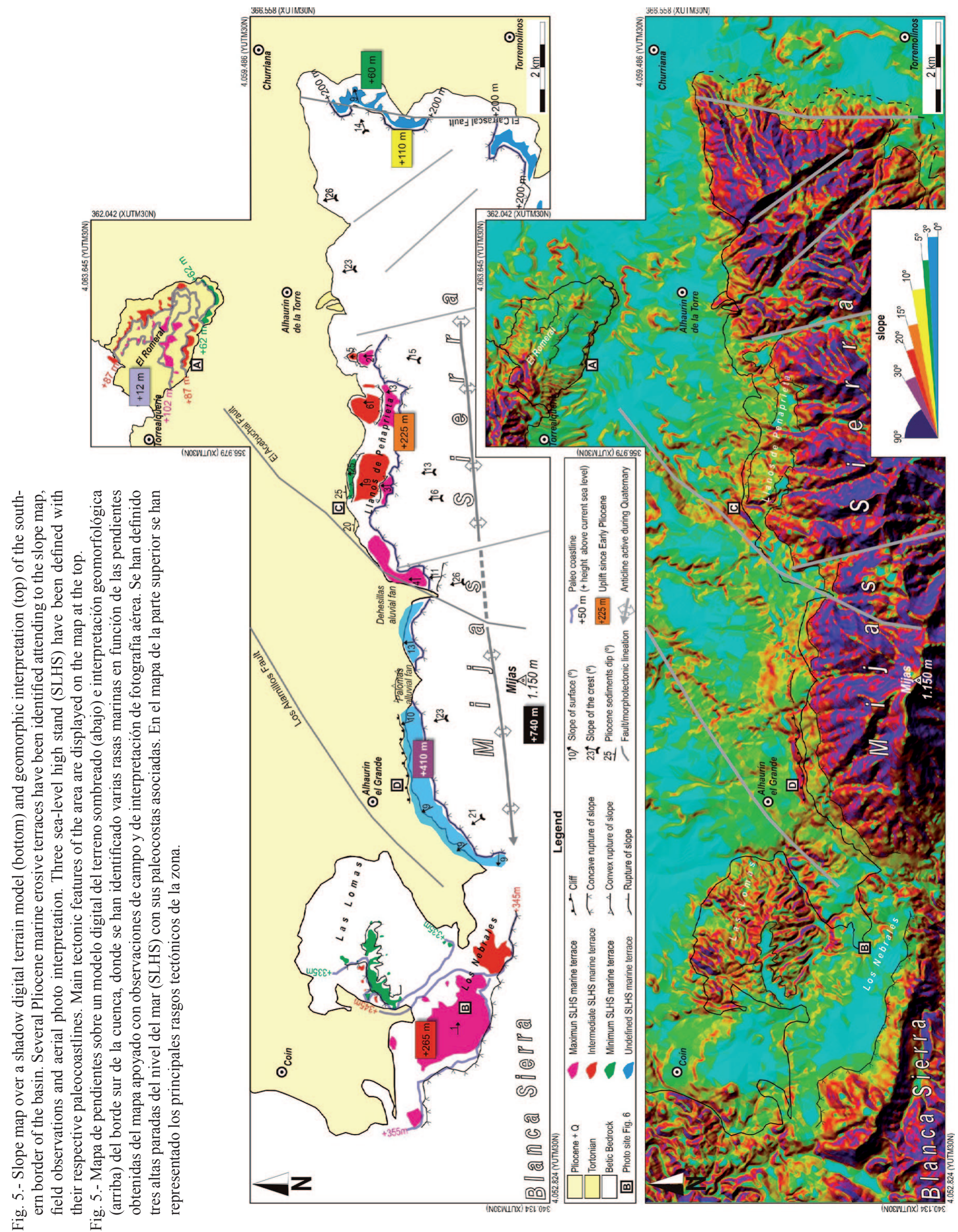


phic heights of the Pliocene marine sediments. We explain this fact considering this part of the Mijas Sierra displays a more pronounced folding, and it is also where the highest topographic altitudes are found (e.g.: Mijas peak, $1150 \mathrm{~m}$ asl).

The easternmost part of the mountain front of Mijas Sierra does not present any signs of marine erosion until the eastern edge of the sierra is reached (on the N-S mountain front close to Torremolinos village). We have identified just one surface, with a paleocoastline at +200 $\mathrm{m}$ acsl, which allows us to estimate an uplift of $110 \mathrm{~m}$ since the Early Pliocene. Nevertheless, the El Carrascal fault, a N-S trending fault, affects this surface showing a vertical offset of $50 \mathrm{~m}$, which gives a vertical slip rate of $0.01 \mathrm{~m} / \mathrm{ky}$ for this fault.

\section{Main active tectonic structures}

The analysis of several morphotectonic features in the Malaga Basin has revealed the presence of several inferred active tectonic structures (Fig. 7). The tectonic deformation throughout the basin is controlled by faults and folds.

\subsection{Kinematics of the active tectonic structures}

The active tectonic structures can be grouped into four major sets:

$N 20^{\circ}-30^{\circ} \mathrm{E}$ set. This set contains three major faults: Sierra de las Nieves fault, La Robla fault and El Carrascal fault. They are high angle faults with vertical movement being the downthrown block the eastern one, accordingly
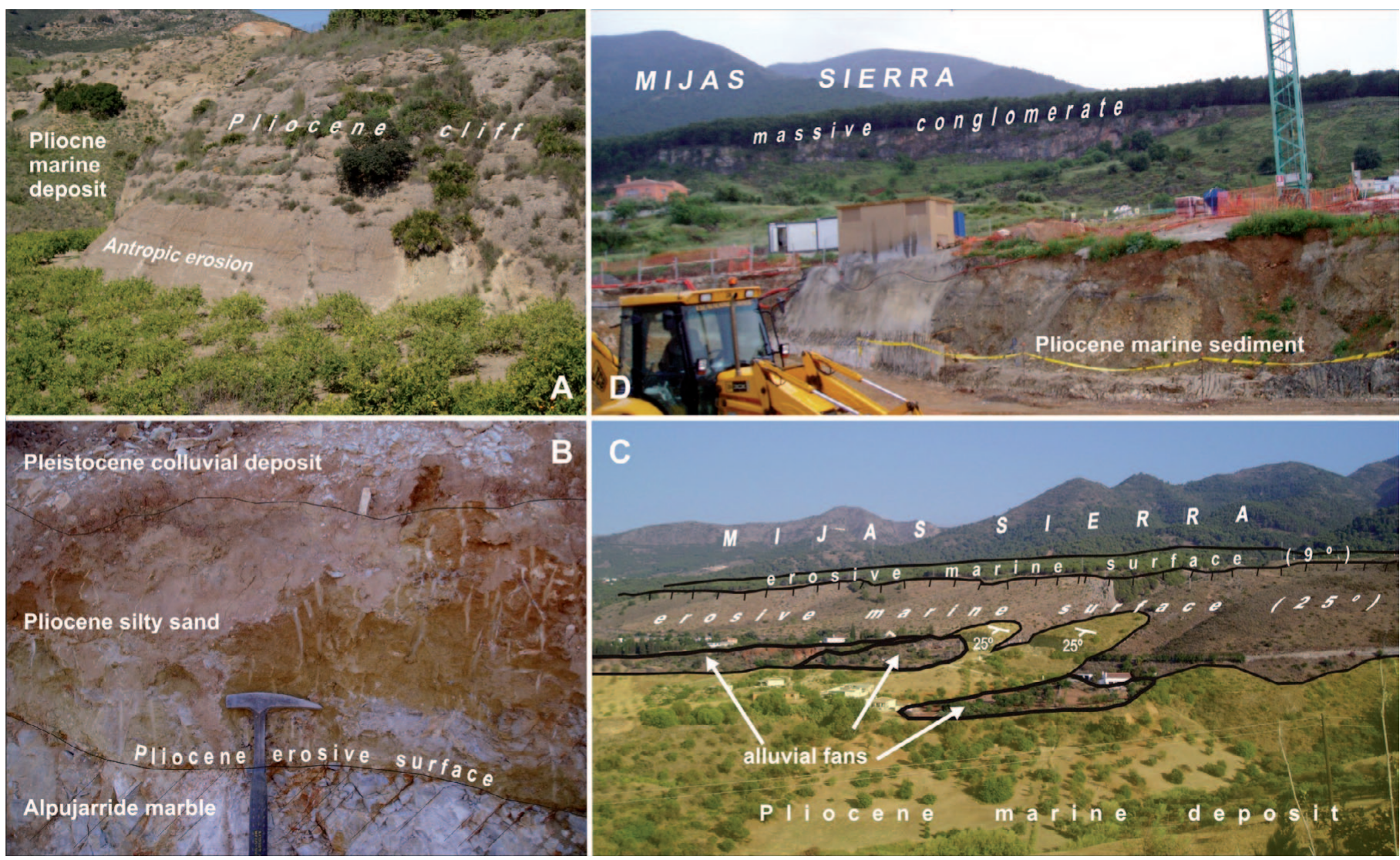

Fig. 6.- A). Subhorizontal Pliocene marine sediments onlapping the Pliocene cliff at El Romeral site. The original morphology of the cliff can be observed at the lower part, where the antropic activity has removed the marine sediments. B) Pliocene marine deposits lying over a marine erosive surface developed on the Alpujarride marble at Los Nebrales site. C) Development of Pliocene marine erosive surfaces over the marbles of Mijas Sierra at Llanos de Peñaprieta site. The slope of the surfaces (in brackets) is controlled by the tectonic deformation of the sierra. D) Pliocene cliff developed over massive conglomerate at the Alhaurin el Grande site. The Pliocene marine sediments are below the alluvial fan deposit in a progradational sedimentary sequence.

Fig. 6.- A) Acantilado plioceno de El Romeral sobre el que se depositan sedimentos marinos pliocenos subhorizontales. La morfología original del acantilado se puede observar en la parte de abajo, donde la acción antrópica ha removido parte de los sedimentos marinos. B) Sedimentos pliocenos marinos depositados sobre una superficie de erosión marina desarrollada sobre mármoles alpujárrides en Los Nebrales. C) Desarrollo de superficies de erosión marina pliocenas sobre los mármoles de la Sierra de Mijas en Llanos de Peñaprieta. La pendiente de las superficies (entre paréntesis) está controlada por la deformación tectónica de la sierra. D) Acantilado plioceno desarrollado sobre conglomerados masivos en Alhaurín el Grande. Los sedimentos pliocenos marinos se sitúan bajo los depósitos de abanico aluvial siguiendo una disposición de secuencia sedimentaria progradante de borde de cuenca. 
to the offset of the Pliocene deposits. We have estimated offsets between 50 and $150 \mathrm{~m}$ since the Early Pliocene, with minimum vertical slip rates between 0.01 and 0.03 $\mathrm{m} / \mathrm{ky}$. El Carrascal fault could be part of a wider shear zone revealed by gravity anomaly maps (Insua-Arévalo et al., 2004b). A minimum total offset of $600 \mathrm{~m}$ is estimated for this fault zone in a wide period of time (Sanz de Galdeano and López-Garrido, 1991), as it can be shown by the control that exerts on the present-day morphology of the coast. The Westernmost faults reach lengths of 11 $\mathrm{km}$. Based on gravity data, El Carrascal fault reaches 9 $\mathrm{km}$ long, and could affect the Pliocene deposits located under the current main stream of the Guadalhorce River (Insua-Arévalo et al., 2004b).

$N 40^{\circ}-50^{\circ} \mathrm{E}$ set. This set consists in three major faults: Alamillos fault, Acebuchal fault and Campanillas fault. They are high angle dip-slip faults and lengths between 7 and $8 \mathrm{~km}$. The Alamillos fault and Acebuchal fault are antithetic faults to each other, with horst morphology in between where Pleistocene alluvial fan deposits are affected. We have estimated a slip rate for these faults between 0.05 to $0.1 \mathrm{~m} / \mathrm{ky}$ since Middle Pleistocene. The Campanillas fault affects Pliocene marine deposits, with a minimum vertical slip rate of $0.02 \mathrm{~m} / \mathrm{ky}$ since the Early Pliocene. We consider that this fault currently controls the Valley of the Campanillas River.

$N 60^{\circ}-85^{\circ} \mathrm{E}$ set. This set includes the main folds highlighted by the morphotectonic analysis: Mijas Sierra anticline, Cartama Sierrra and Villafranco de Guadalhorce anticlines, and Malaga Mountains anticline (Fig. 8).

It is noteworthy to point out that no faults with surface rupture running along this trend controls any mountain front currently. The only active faults with this trend must be blind faults associated to folds (Fig. 9).

Considering the tectonic evolution and the deep crustal structure of this part of the Betic Cordillera (Insua-Arévalo, 2008), we propose a working hypothesis based on a model with two complex blind faults (Fig. 9A). The south branch, with geometry on flats and ramps, would be the responsible for the folding of the Mijas Sierra, and Cartama Sierra and Villafranco de Gualdahorce folds. The north branch, with a smoother geometry, would be the responsible for the folding of the Malaga Mountains. Both branches merge in a regional decollement level located at $12-13 \mathrm{~km}$ depth. This model, in its most upper part, is based on the analogue pattern of folding proposed for the Bajo Segura fault, located in the Eastern Betic Cordillera (Taboada et al., 1993; Alfaro et al., 2002) (Fig. 9B).

$N 165^{\circ}-170^{\circ} \mathrm{E}$ set. This set of faults includes several discontinuous faults with no clear morphological expression that we consider as tear faults. These faults limit laterally the deformation related to the main process of folding of the basin and surrounding mountains (Fig. 8). Nevertheless, we have found a vertical offset of $160 \mathrm{~m}$ in the Guadalmedina fault affecting Pliocene marine sediments, giving a minimum vertical slip rate of $0.03 \mathrm{~m} / \mathrm{ky}$. These values are anomalously high for this type of tear faults, what make us to speculate that some of these faults could accommodate part of the vertical movements of the basin, as it was described above (section 3.3).

\subsection{Seismic potential of the Malaga Basin}

The assessment of the seismic potential of the main active structures in the Malaga Basin is of great interest for future seismic hazard analysis. Few works deal with the task of estimating empirically earthquakes moment magnitude from fault geometry parameters (e.g.: Wells and Coppersmith, 1994; Vakov, 1996; Stirling et al., 2002). In this work, we use the relationships proposed by Wells and Coppersmith (1994) attending to the kinematic and geometry of the faults sets described above. We have estimated moment magnitude $\left(\mathrm{M}_{\mathrm{w}}\right)$ in relation with two of the fault parameters that can be assessed from the geomorphic analysis: surface rupture length (SRL) and/ or rupture area (RA) (Table 1).

Three rupture hypotheses $\left(\mathrm{H}_{1}, \mathrm{H}_{2}\right.$ and $\left.\mathrm{H}_{3}\right)$ have been considered for each of the two branches of the blind faults included in the $\mathrm{N} 60^{\circ}-85^{\circ} \mathrm{E}$ set (Fig. 9). The first hypothesis $\left(\mathrm{H}_{1}\right)$ takes into account the coseismic rupture of the upper flat of each branch (north and south). The south branch is more affected by the tear faults of the $\mathrm{N} 165^{\circ}-170^{\circ} \mathrm{E}$ set than the north branch. This fact gives us larger values of SRL and RA for the north branch. The second hypothesis $\left(\mathrm{H}_{2}\right)$ considers the rupture of the deepest part of the faults (the ramps). In this case, the faults are not limited by the tear faults, which would not reach to affect all the seismogenic crustal thickness. Finally, the third hypothesis $\left(\mathrm{H}_{3}\right)$ assumes the total rupture of each of the branches (flat + ramp). In this hypothesis, we consider that the rupture of the upper flat of the south branch would not be affected by the tear faults, but the rupture would involve the whole flat simultaneously.

We have not considered the $\mathrm{N} 165^{\circ}-170^{\circ} \mathrm{E}$ set of faults as significant seismogenic sources, since their rupture takes place because of the lateral variation of the deformation produced by the folding associated with the blind faults. In such a strain environment, the rupture responds to local stress tensors, with strong variation in both, magnitude and orientation of the stress axes. This variation depends on the relative movements on both sides along the fault, where low magnitude earthquakes would be associated with local ruptures. Notice that the seismic energy release by these minor earthquakes will not ever be as 
Fig. 7.- Main active tectonic structures of the Malaga Basin and surrounding areas. (SN) Sierra de las Nieves Fault, (LR) La Robla Fault, (AL) Los Alamillos Fault, (AC) Acebuchal Fault, (CR) El Carrascal Fault, (CP) Campanillas Fault, (GM) Guadalmedina Fault.

Fig. 7.- Principales estructuras activas de la Cuenca de Málaga y sus relieves circundantes. (SN) Falla de la Sierra de las Nieves, (LR) Falla de La Robla, (AL) Falla de los Alamillos, (AC) Falla del Acebuchal, (CR) Falla del Carrascal, (CP) Falla de Campanillas, (GM) Falla del Guadalmedina.
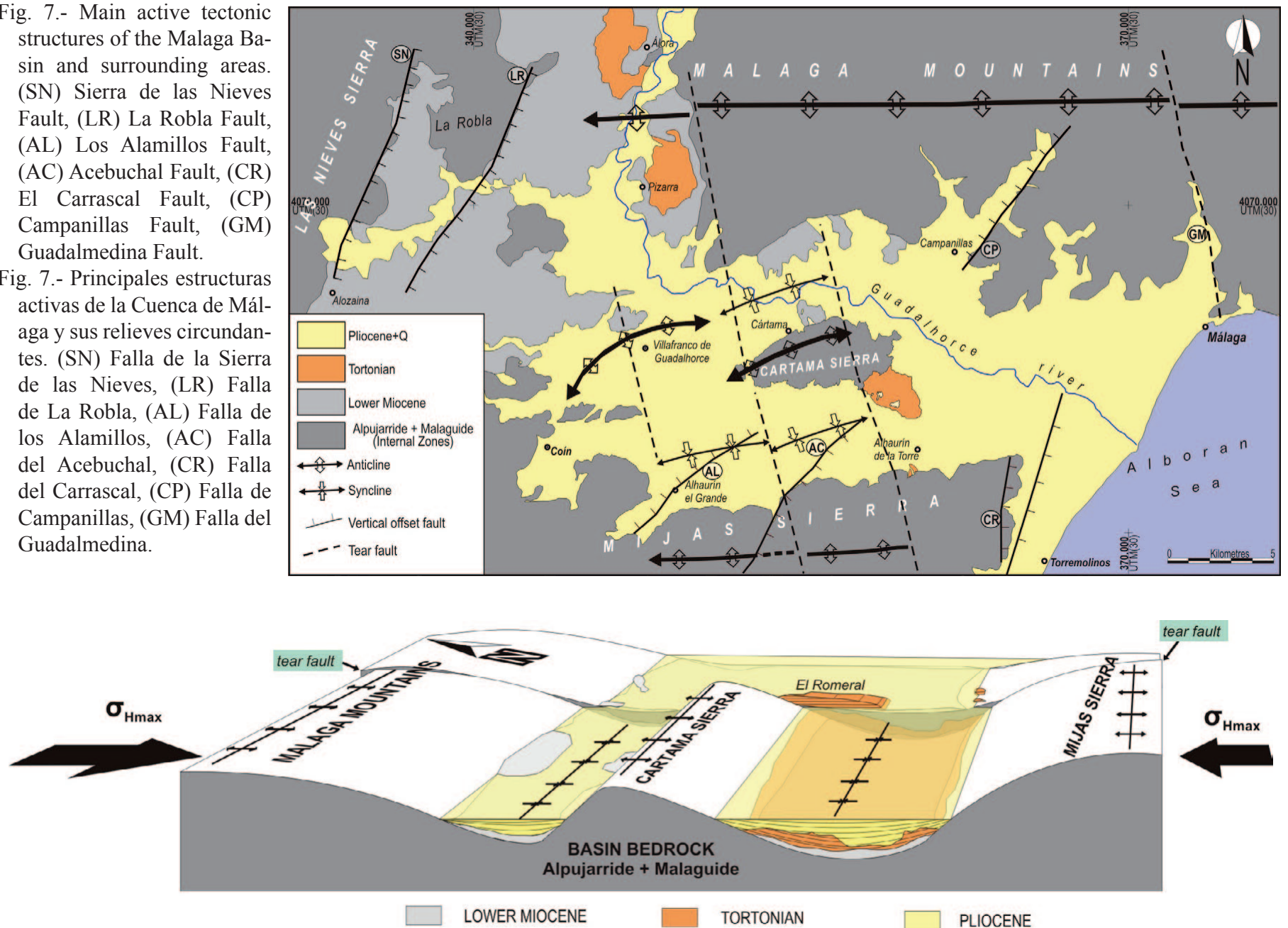

Fig. 8.- Simplified sketch showing the folding of the Malaga Basin. The folds are laterally limited in some cases by tear faults belonging to the $\mathrm{N} 165^{\circ}-170^{\circ} \mathrm{E}$ set.

Fig. 8.- Bloque diagrama simplificado en el que se muestra el plegamiento de la Cuenca de Málaga. Los pliegues están limitados a veces lateralmente por fallas de transferencia pertenecientes a la familia $165^{\circ}-170^{\circ} \mathrm{E}$.

Fig. 9.- A. Relationship between folding and blind faults in the Malaga Basin. North and South branches are defined considering both the tectonic evolution and the deep crustal structure of this part of the cordillera (Insua-Arévalo, 2008). B. Analogue model of fault-related folds defined for the Bajo Segura blind fault in the Eastern Betic Cordillera (Modified from Taboada et al., 1993).

Fig. 9.- A. Relación entre los pliegues de la Cuenca de Málaga y fallas ocultas. La presencia de las ramas norte y sur se basa en la evolución tectónica y la estructural cortical profunda de esta parte de la cordillera obtenida de datos geofísicos (Insua-Arévalo, 2008). B. Modelo análogo de plegamiento relacionado con fallas ocultas definida para la falla del Bajo Segura en la Cordillera Bética Oriental (modificada de Taboada et al., 1993).

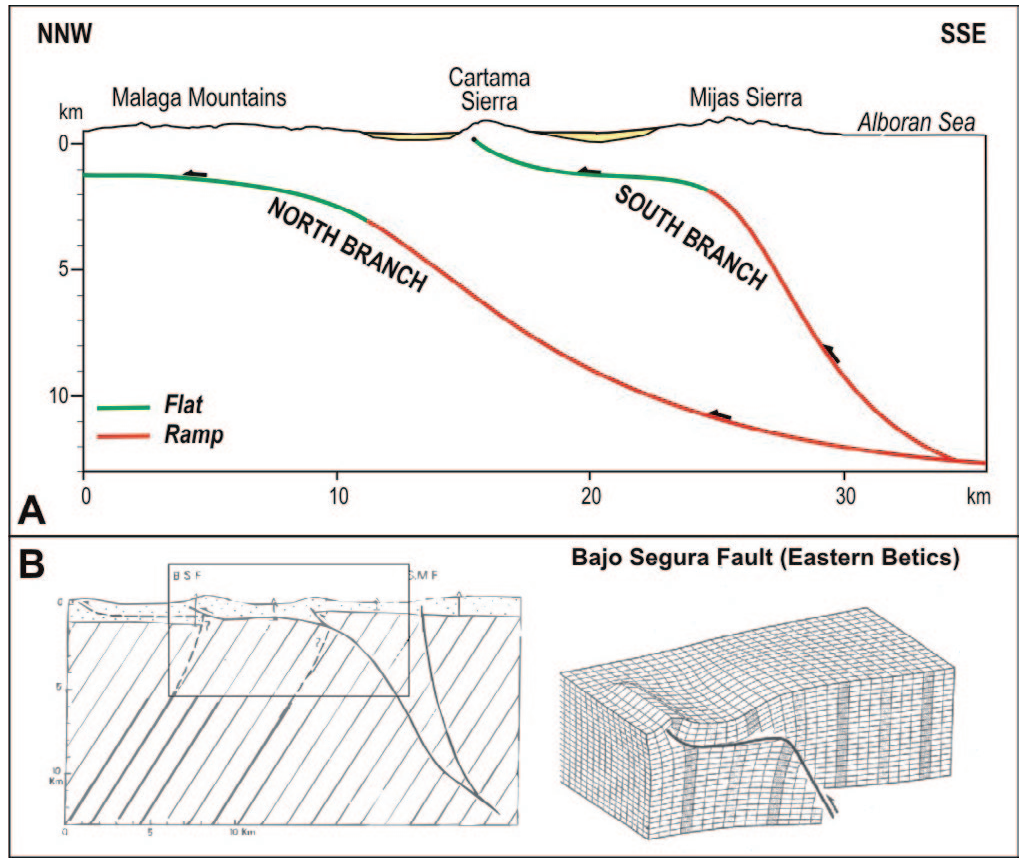




\begin{tabular}{|c|c|c|c|c|c|c|c|c|}
\hline & \multirow[b]{3}{*}{$\mathrm{N} 20^{\circ}-30^{\circ} \mathrm{E}$} & \multirow[b]{3}{*}{$\mathrm{N} 40^{\circ}-50^{\circ} \mathrm{E}$} & \multicolumn{6}{|c|}{$\mathrm{N} 60^{\circ}-85^{\circ} \mathrm{E}$} \\
\hline & & & \multicolumn{3}{|c|}{$\mathrm{S}$ branch } & \multicolumn{3}{|c|}{$\mathrm{N}$ branch } \\
\hline & & & $\begin{array}{c}\mathbf{H}_{1} \\
\text { Flat }\end{array}$ & $\begin{array}{l}\mathbf{H}_{2} \\
\operatorname{ramp}\end{array}$ & $\begin{array}{c}\mathbf{H}_{3} \\
\text { whole }\end{array}$ & $\begin{array}{l}\mathbf{H}_{1} \\
\text { flat }\end{array}$ & $\underset{\operatorname{ramp}}{\mathbf{H}_{2}}$ & $\begin{array}{c}\mathbf{H}_{3} \\
\text { whole }\end{array}$ \\
\hline $\begin{array}{l}\text { Surface Rupture } \\
\text { Length }(\mathbf{k m})\end{array}$ & $9-11$ & $7-8$ & $7-8$ & 21 & & 22 & $>26$ & \\
\hline Rupture Area $\left(\mathrm{km}^{2}\right)$ & & & 70 & 315 & 525 & 242 & $>676$ & 962 \\
\hline M $f(\mathbf{S R L})$ & $6.16-6.27$ & $6.06-6.10$ & $\begin{array}{l}6.03- \\
6.10\end{array}$ & 6.61 & & 6.64 & $>6.73$ & \\
\hline M $f(\mathbf{R A})$ & & & 5.99 & 6.58 & 6.78 & 6.48 & $>6.88$ & 7.01 \\
\hline $\begin{array}{l}\text { Maximum asigned } \\
\text { magnitude }\end{array}$ & 6.2 & 6.1 & 6.0 & 6.6 & 6.8 & 6.5 & 6.9 & 7.0 \\
\hline
\end{tabular}

Table 1.- Estimation of the seismic potential of the main active tectonic structures of the Malaga Basin inferred by the morphotectonic analysis. Moment magnitudes $\left(\mathrm{M}_{\mathrm{w}}\right)$ have been obtained using the empirical relationship of Wells and Coppersmith (1994) on surface rupture length (SRL) and/or rupture area (RA). See details in the main text for the different hypotheses $(\mathrm{H})$ taken into account for branches $\mathrm{N}$ and $\mathrm{S}$ of the faults belonging to the $\mathrm{N} 60^{\circ}-85^{\circ} \mathrm{E}$ set.

Tabla 1.- Estimación del potencial sísmico de las principales estructuras tectónicas activas de la Cuenca de Málaga inferidas del análisis morfotectónico. El cálculo de la magnitud momento ( $\mathrm{Mw}$ ) se ha realizado en función de la longitud de la ruptura en superficie (SRL) y/o del área de ruptura (RA) según las relaciones empíricas de Wells y Coppersmith (1994). Las hipótesis adoptadas para la ruptura de las ramas N y S de la familia $\mathrm{N}^{\circ} 0^{\circ}-85^{\circ} \mathrm{E}(\mathrm{H}) \mathrm{se}$ detallan en el texto.

large as it would be if we consider the rupture of the total length of the faults.

As shown in Table 1, the active faults of the Malaga Basin could generate earthquakes with a maximum magnitude $\left(\mathrm{M}_{\mathrm{w}}\right)$ between 6.0 and 7.0. These results are consistent with the magnitudes assigned to the historical events of 1494 and 1680 (FAUST, 2011; Martínez-Solares and Mezcua, 2002). Vertical faults from the $\mathrm{N} 20^{\circ}-30^{\circ} \mathrm{E}$ and $\mathrm{N} 40^{\circ}-50^{\circ} \mathrm{E}$ sets will generate low-magnitude earthquakes $(6.1 \leq \mathrm{Mw} \leq 6.2)$, while blind thrust faults will produce earthquakes of larger magnitude $(6.5 \leq \mathrm{Mw} \leq 7.0)$. However, the individual rupture of some of the flats of the south branch of the blind faults could also generate smaller magnitude earthquakes $(\mathrm{Mw}=6.0)$.

\section{Conclusions}

The Malaga Basin shows a diffuse active tectonic deformation that has been analyzed attending to geomorphological features.

The Plio-Quaternary alluvial fans located on the southern border of the basin (Mijas Sierra), where three depositional phases have been identified, show several morphotectonic features that evidence two different sectors along the mountain front. The western sector shows a tectonic uplift of the source area; meanwhile the eastern sector has no clear signs of tectonic activity. The two sectors are put in contact by the El Acebuchal fault, a vertical $\mathrm{N} 43^{\circ} \mathrm{E}$ trending fault that affect both, the Mijas Sierra, and the alluvial fan deposits. This fault has a minimum vertical slip rate of $0.05 \mathrm{~m} / \mathrm{ka}$ since the Middle Pleistoce- ne. Towards the West, and parallel to this fault, runs the Los Alamillos fault, with a minimum vertical slip rate of $0.05 \mathrm{~m} / \mathrm{ka}$ for the same period.

The central part of the basin shows two en-echelon active folds: Cartama Sierra and Villafranco de Guadalhorce affecting to the drainage network. The former, developed from an alpine structure, shows a westwards preferential lateral propagation. The latter is a neotectonic fold with a symmetrical lateral growing. Both of them could be related to blind faults in depth.

We have identified several levels of Pliocene marine erosive surfaces, which together with the Pliocene marine sediments located throughout the basin, have been used as tectonic markers. These markers reveal a complex deformation of the basin controlled not only by faults, but by important processes of folding involving the Malaga Mountains and the Mijas Sierra. We have identified three vertical faults (La Robla fault, Sierra de las Nieves fault, and Campanillas fault) with a $\mathrm{N} 20^{\circ}-30^{\circ} \mathrm{E}$ trending and a Plio-Quaternary minimum vertical slip rate of $0.02-0.03 \mathrm{~m} / \mathrm{ka}$.

Finally, we have estimated by empirical relationships the seismic potential of the main active structures of the basin inferred by the morphotectonic analysis, which could reach magnitudes $\left(\mathrm{M}_{\mathrm{w}}\right)$ between 6.0 and 7.0.

\section{Acknowledgements}

The authors gratefully acknowledge the carefully review by Dr. Carlos Sanz de Galdeano and Dr. Patricia Ruano, whose suggestions and advice have improve the understanding of this work. 


\section{References}

Alfaro, P., Andreu, J.M., Delgado, J., Estévez, A., Soria, J.M., Teixidó, Y. (2002): Quaternary deformation of the Bajo Segura blind fault (eastern Betic Cordillera, Spain) revealed by high-resolution reflection profiling. Geological Magazine 139(3), 331-341. doi:10.1017/ S0016756802006568.

Andreo, B., Sanz de Galdeano, C. (1994): Structure of the Sierra de Mijas (Alpujárride Complex, Betic Cordillera). Annales Tectonicae 8(1), 23-35.

Barranco, L., Ansorge, J., Banda, E. (1990): Seismic refraction constraints on the geometry of the Ronda peridotitic massif (Betic cordillera, Spain). Tectonophysics 184, 379-392. doi:10.1016/00401951(90)90450-M.

Booth-Rea, G., Azañón, J.M., García-Dueñas, V., Augier R., SánchezGómez, M. (2003): A ‘core-complex-like structure’ formed by superimposed extension, folding and high-angle normal faulting. The Santi Petri dome (western Betics, Spain). Comptes rendus Geoscience 335(2), 265-274.

Bourgois, J. (1978): La transversale de Ronda (Cordillères bétiques, Espagne). Donnés géologiques pour un modéle d'evolution de l'arc de Gibraltar. PhD Thesis (published in: Annales scientifiques de l'Université de Besançon, Géologie 30), Universidad de Besançon: $445 \mathrm{p}$.

Braga, J.C, Martín, J.M., Quesada, C. (2003): Patterns and average rates of late Neogene-Recent uplift of the Betic Cordillera, SE Spain. Geomorphology 50, 3-26. doi: 10.1016/S0169-555X(02)00205-2.

Calvert, A., Sandvol, E., Seber, D., Barazangi, M., Roecker, S., Mourabit, T., Vidal, F., Alguacil, G., Jabour, N. (2000): Geodynamic evolution of the lithosphere and upper mantle beneath the Alboran region of the western Mediterranean: constraints from travel time tomography. Journal of Geophysical Research 105, 10871-10898. doi:10.1029/2000JB900024.

Capote, R., Insua-Arévalo, J. M., Martínez-Díaz, J. J., MartínGonzález, F., Tsige, M. (2002): La Sierra de Cártama: Pliegue con actividad reciente en las Béticas Occidentales (Hoya de Málaga). Geogaceta 31, 135-138.

Chamón, C., Quinquer, R. (1976): Hoja Geológica num. 1052 (Álora). Mapa Geológico de España E. 1:50.000. Segunda serie, I.G.M.E., Madrid.

Delcaillau, B., Carozza, J.M., Lavilla, E., Amrhar, M., Sheikholeslami, R. (2007): New geomorphic criteria on lateral propagation of blind thrust-related fold growth accommodating oblique convergence. Zeitschrift für Geomorphologie N.F. 51(2), 141-163. doi: 10.1127/0372-8854/2007/0051-0141.

Estévez-González, A., Chamón, C. (1978a): Hoja Geológica num. 1053/67 (Málaga-Torremolinos). Mapa Geológico de España E. 1:50.000. Segunda serie, I.G.M.E., Madrid.

Estévez-González, A., Chamón, C. (1978b): Hoja Geológica num. 1066 (Coín). Mapa Geológico de España E. 1:50.000. Segunda serie, I.G.M.E., Madrid.

FAUST, Research Project: The European Catalogue of seismogenic sources. Search in the database on September, 2011. http://faust. ingv.it/current_2.htm.

Galindo-Zaldivar, J. F., González-Lodeiro, A., Jabaloy, A. (1993): Stress and paleostress in Betic-Rif cordilleras (Miocene to present-day). Tectonophysics 227, 105-126. doi:10.1016/00401951(93)90090-7.

González-Lodeiro, F., Aldaya, F., Galindo-Zaldivar, J., Jabaloy, J.C. (1996): Superimpositon of extensional detachments during the Neogene in the internal zonesof the Betic cordilleras. Geologische Rundschau 85, 350-362. doi:10.1007/BF02422240.

Guerra-Merchán, A., Serrano, A., Ramallo, D. (2000): El Plioceno de la Cuenca de Málaga (Cordillera Bética). Geotemas 1(2), 107-110.

Haq, B.U., Hardenbol, J., Vail, P.R. (1987): Chronology of fluctuating sea levels since the Triassic. Science 235, 1156-1166.

Houseman, G. (1996): Earth science; from mountains to basin. Nature 379(6568), 771-772. doi:10.1038/379771a0.

Insua-Arévalo, J.M. (2008) Neotectónica y Tectónica Activa de la Cuenca de Málaga (Cordillera Bética Occidental). PhD Thesis. Universidad Complutense de Madrid, Madrid: 265 p.

Insua-Arévalo, J.M., Capote, R., Martín-González, F., Martínez-Díaz, J.J. (2004a): Análisis de la sinuosidad del Bajo Guadalhorce y sus implicaciones en la actividad tectónica reciente en la Cuenca de Málaga. Geotemas 6(3), 259-261.

Insua-Arévalo, J.M., Martín-González, F., Capote, R., Martínez-Díaz, J.J. (2004b): Análisis tectónico de los mapas de anomalía gravimétrica de la Cuenca de Málaga (Béticas Occidentales). Boletín Geológico y Minero 115(3), 521-536.

Jackson, J., Norris, R., Youngson, J. (1996): The structural evolution of active fault and fold systems in central Otago, New Zealand: evidence revealed by drainage patterns. Journal of Structural Geology 18(2-3), 217-234. doi:10.1016/S0191-8141(96)80046-0.

Lonergan, L., White, N. (1997): Origin of the Betic-Rif mountain belt. Tectonics 16(3), 504-522. doi:10.1029/96TC03937.

López-Garrido, A.C., Sanz de Galdeano, C. (1999): Neogene sedimentation and tectonic-eustatic control of the Málaga Basin, South Spain. Journal of Petroleum Geology 22 (1), 81-96.

Martín-Algarra, A. (coord.), Alonso-Chaves, F.M., Andreo, B., Azañón, J.M., Balanyá, A., Booth-Rea, G., Crespo-Blanc, A., Delgado, F., Estévez, F., García-Casco, A., García-Dueñas, V., Garrido, C.J., Gervilla, F., González-Lodeiro, A., López-Garrido, A.C., Orozco, M., Sánchez-Gómez, M., Sánchez-Navas, A., Sanz de Galdeano, C., Soto, J.I., Torres-Roldán, R.L. (2004): Complejo Alpujárride. In: J.A. Vera (ed.), Geología de España. S.G.E.-I.G.M.E., Madrid: 409-422.

Martínez-Díaz, J.J. (2000): Neotectónica y tectónica activa de la Falla de Las Viñas: influencia de las perturbaciones del campo de esfuerzos regional generadas por la Falla de Alhama de Murcia. Boletín Geológico y Minero 111 (1), 33-52.

Martínez-Solares, J.M., Mezcua, J. (2002): Catálogo sísmico de la Península Ibérica (880 a. C. - 1900). Monografía nº 18. I.G.N., Madrid: $253 \mathrm{p}$.

Mon, R. (1971). Estudio geológico del extremo occidental de los Montes de Málaga y Sierra de Cartama (Prov. de Málaga). Boletín Geológico y Minero 82-83, 132-146.

Morales, J., Serrano, I., Jabaloy, A., Galindo-Zaldívar, J., Zhao, D., Torcal, F., Vidal, F. González Lodeiro, F. (1999): Active continental subduction beneath the Betic Cordillera and the Alboran Sea. Geo$\log y 27,735-738$.

Platt, J.P., Vissers, R.L.M. (1989): Extensional collapse of thickened continental lithosphere; a working hypothesis for the Alboran Sea and Gibraltar Arc. Geology 17, 540-543. doi:10.1130/00917613(1989)017<0540:ECOTCL>2.3.CO;2.

Sanz de Galdeano, C. Alfaro, P. (2004): Tectonic significance of the present relief of the Betic Cordillera. Geomorphology 63(3-4), 175190. doi:10.1016/j.geomorph.2004.04.002.

Sanz de Galdeano, C., López-Garrido, A.C. (1991): Tectonic evolution of the Málaga Basin (Betic Cordillera) Regional Implication. Geodinamica Acta 5(3), 173-186.

Sanzde Galdeano, C., Vera, J.A. (1992): Stratigraphic record and palaeogeographical context of the Neogene basins in the Betic Cordillera, Spain. Basin Research 4(1), 21-36. doi:10.1111/j.1365-2117.1992. tb00040.x.

Schoorl, J.M., Veldkamp, A. (2003): Late Cenozoic landscape development and its tectonic implications for the Guadalhorce valley near 
Álora (Southern Spain). Geomorphology 50, 43-57. doi:10.1016/ S0169-555X(02)00207-6.

Schumm, S.A. (1977): The fluvial System. Wiley \& Sons, New York: $338 \mathrm{p}$.

Schumm, S.A., Dumont, J.F., Holbrook, J.M. (2000): Active Tectonics and Alluvial Rivers. Cambridge University Press, Cambridge: 276 p.

Silva, P.G. (1994): Evolución geodinámica de la Depresión del Guadalentín desde el Mioceno superior hasta la actualidad. $\mathrm{PhD}$ Thesis, Universidad Complutense de Madrid, Madrid: $642 \mathrm{p}$.

Silva, P.G., Goy, J.L., Zazo, C., Bardají, T. (1992): Evaluación geomorfológica de la actividad tectónica cuaternaria a lo largo de frentes montañosos de falla en el SE de España. Actas III Cong. Geol. Esp. Vol. 2, Salamanca: 96-100.

Silva, P.G., Goy, J.L., Zazo, C., Bardají, T. (2003): Fault-generated mountain fronts in southeast Spain: geomorphologic assessment of tectonic and seismic activity. Geomorphology 50, 203-225. doi:10.1016/S0169-555X(02)00215-5.

Stirling, M., Rhoades, D., Berryman, K. (2002): Comparison of Earthquake Scaling Relations Derived from Data of the Instrumental and Preinstrumental Era. Bulletin of the Seismological Society of America 92(2), 812-830. doi:10.1785/0120000221.
Taboada, A., Bousquet, J.C., Philip, H. (1993): Coseismic elastic models of folds above blind thrusts in the Betic Cordilleras (Spain) and evaluation of seismic hazard. Tectonophysics 220, 223-241. doi:10.1016/0040-1951(93)90233-A.

Torné, M., Banda, E. (1992): Crustal thinning from the Betic Cordillera to the Alboran Sea. GeoMarine Letters 12, 76-81. doi:10.1007/ BF02084915.

Torné, M., Banda, E., García-Dueñas, V., Balanyá, J. C. (1992): Mantle-lithosphere bodies in the Alboran crustal domain (Ronda peridotites, Betic-Rif orogenic belt). Earth and Planetary Science Letters 110, 163-171. doi:10.1016/0012-821X(92)90046-X.

Vakov, A.V. (1996): Relationshipes between earthquake magnitude, source geometry and slip mechanism. Tectonophysics 261, 97-113. doi:10.1016/j.tecto.2007.11.004.

Wells, D. L., Coppersmith, K.J. (1994): New empirical relationships among magnitude, rupture length, rupture area, and surface displacement. Bulletin of the Seismological Society of America 84(4), 974-1002.

Zeck, H.P. (1996): Betic-Rif Orogeny; subduction of Mesozoic Tethys lithosphere under eastward drifting Iberia, slab detachment shortly before $22 \mathrm{Ma}$, and subsequent uplift and extensional tectonics. Tectonophysics 254(1-2), 1-16. doi:10.1016/j.tecto.2009.07.001. 
